E

N422

NMAIREF

V. 21 pt. 2

CONTRIBUTIONS FROM THE MUSEUM OF THE AMERICAN INDIAN HEYE FOUNDATION

VOL. XXI, PART 2

\title{
ANNOTATED BIBLIOGRAPHY OF AMERICAN INDIAN PAINTING
}

\author{
Compiled by \\ DORIS OSTRANDER DAWDY
}

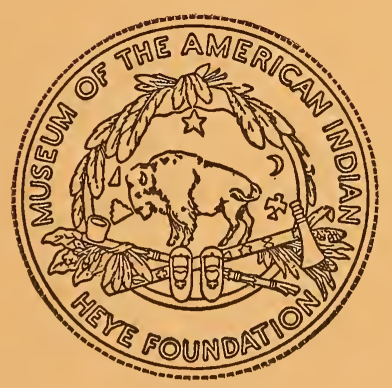

NEW YORK

MUSEUM OF THE AMERICAN INDIAN

HEYE FOUNDATION

1968 



\author{
CONTRIBUTIONS FROM THE \\ MUSEUM OF THE AMERICAN INDIAN \\ HEYE FOUNDATION \\ VOL. XXI, PART 2
}

\title{
ANNOTATED BIBLIOGRAPHY OF AMERICAN INDIAN PAINTING
}

Compiled by

DORIS OSTRANDER DAWDY

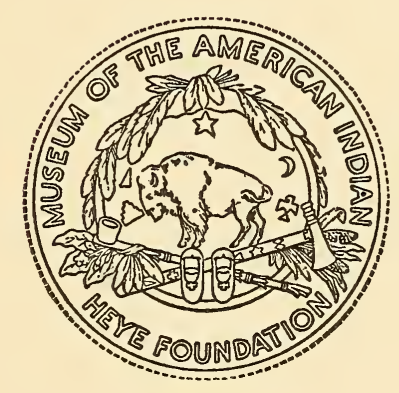

NEW YORK

MUSEUM OF THE AMERICAN INDIAN

HEYE FOUNDATION

1968 
Library of Congress catalog card number 66-27358

Printed in Germany at J.J. Augustin, Glückstadt 


\section{INTRODUCTION}

Contemporary American Indian painting began with the discovery by Indians that they could paint with white men's tools and materials. They had, however, little inclination to adopt the European or academic approach to painting. Products as they were of an ancient ancestry, they followed a law of perspective quite different from that of the Western world.

Indian painters did not need models, nor did they proceed in piecemeal fashion-sketching and erasing, measuring and rearranging. As Mary Austin said, the artist "simply selected a subject from his own mind, sat down with a blank piece of paper and a pencil, began in the lower left hand corner and continued on steadily until the whole composition lay before him complete in every detail."* Many Indian painters abandoned preliminary sketching and relied solely on their phenomenal memories.

The rare ability to retain in mind the entire concept for a painting made it possible for Pueblo artists to paint ceremonial dancers in suspended action; for Sioux artists to depict the violent action of the hunt; for Navajo and Apache artists to paint deer vaulting clumps of bushes, or their beloved horses racing across uncluttered landscapes.

Quite naturally white artists were impressed, and even influenced. Some expressed their appreciation in a manner most beneficial to Indian painting. John Sloan organized the Exposition of Indian Tribal Arts to publicize and exhibit the work of Indian artists in this country and in Europe. The College Art Association arranged traveling exhibitions. Ernest Blumenschein, Bert Phillips, Marsden Hartley and others wrote analytical articles about Indian painting. Throughout the nineteen twenties and thirties, there was a concerted effort to obtain recognition for this important new discovery.

The first recognized Indian artists were from San Ildefonso Pueblo near Santa Fe, New Mexico. Crescencio Martínez began his career about IgIo, when he volunteered to paint buffalo and eagle dancers in ceremonial costume in water color for Dr. Edgar L. Hewett, then Director of the School of American Research. Such paintings had considerable ethnological significance, and the demand for them undoubtedly influenced the trend Pueblo Indian painting was to take. Alfred Montoya began to record the ceremonial life of his people about I9I5. Then Alfonso Roybal, better known by his Indian name, Awa Tsireh, began a career which was to give great impetus to Indian painting. Awa Tsireh was an innovator, passing through several periods in his long life of artistic production. Tonita Peña and Julián Martínez also contributed much to San Ildefonso's reputation in the newly-founded art movement.

From the Zia artist, Velino Herrera, and Hopi artist Fred Kabotie, have come the modeled figure presenting the third-dimensional quality so rare * Mary Austin, "American Indian Murals," The American Magazine of Art, XXVI (August 1933), 380. 
in most early Indian painting. Fred Kabotie and Otis Polelonema are the first Hopi artists of note. Polelonema began painting around I9I5; Kabotie about five years later. All three artists have had long and successful careers.

Kiowa painting began about I9I8, and received recognition through the efforts of Miss Susan Peters, an Indian Service field worker, and Professor O. B. Jacobson, who for many years was head of the art department at the University of Oklahoma. In I928, paintings by Monroe Tsa-to-ke, Stephen Mopope, Jack Hokeah, Spencer Asah, James Auchiah and Miss Bou-ge-tah Smokey were sent to the International Art Exhibition in Prague, Czechoslovakia. It created tremendous interest and opened the way for further exhibitions in Europe.

The Kiowa group was augmented by other Plains Indian artists, such as the late Acee Blue Eagle (Creek-Pawnee). Woodland tribes followed with still another influence on Indian painting - that of Fred Beaver (Creek-Seminole), and many others.

Navajo painting made its appearance during the nineteen thirties. It received its greatest impetus under Dorothy Dunn, then head of the newly established art department at the Santa Fe Indian School in New Mexico. Harrison Begay, Gerald Nailor, Andrew Tsihnahjinnie, and Quincy Tahoma were among her first students; all became prominent artists. The standards set by these early Navajo artists have never been surpassed.

Apache painting developed contemporaneously with that of the Navajo. Allan Houser, who is related to the famous Geronimo, does outstanding work. In addition, he is a sculptor and an art teacher. In general, Apache painting resembles Navajo painting, which is not surprising, since their ethnological backgrounds have a common origin.

A number of contemporary Indian artists have been pace setters, developing unique and individual styles of painting not specifically associated with their Pueblo or tribe. The following are good examples: Oscar Howe (Sioux), Pablita Velarde (Santa Clara), Richard West (Cheyenne), Albin Jake (Pawnee), Joe Herrera (Cochití), Pop Chalee (Taos), Carl Woodring (Osage), and Gerónima Montoya (San Juan). They have done considerable research on primitive art forms found in pottery, basketry, pictographs, sand paintings, and kiva murals. This knowledge manifests itself in many an abstract painting, completely modern in concept and execution. Some of these artists have had college art work and several possess degrees in art; but all have training in traditional Indian painting.

There are Indian artists who have missed contact with Indian painting techniques until rather late in their careers. Yeffe Kimball (Osage), George Morrison (Chippewa), and Helen Boswell (Cherokee) are in this category. Though they exhibit occasionally at Indian painting exhibitions, their careers have been built upon competition in the non-Indian art world. They exhibit widely, and usually without reference to their Indian ancestry. A substantial portion of their work shows no readily apparent Indian influence. Yet these artists remain basically and loyally Indian, with much of their inspiration derived from their ancestral heritage. 
In 1928, Europe recognized American Indian painting and reserved for it a place in world art. During the years which followed, various European countries became intimately acquainted with its merit. But the event which Indian artists will remember always is the presentation by the French Government in I954 of Palmes Académique to eight members of their group. The honor was awarded to Harrison Begay, Fred Kabotie, Joe Herrera, Pablita Velarde, Allan Houser, Awa Tsireh, Andrew Tsihnahjinnie, and Velino Herrera.

Prominent individuals and organizations in this country, realizing the significance of this new art movement, collected representative work to show the development of Indian painting from Igro to the present time. The Indian Arts Fund paintings are at the Museum of New Mexico in Santa Fe; the Denver Museum collection is at Chappell House in Denver. Particularly representative collections, in that they include many Woodland and Plains Indian paintings, are at Philbrook Art Center and Thomas Gilcrease Institute in Tulsa, Oklahoma; perhaps the most diverse large collection is that of the Museum of the American Indian, Heye Foundation. Many other museums have Indian paintings in their permanent collections.

Sixty years of Indian painting is a short time in the annals of history. On so brief a past it is impossible to hazard a guess about the future. But one thing is certain: an atmosphere of vigilance and encouragement must prevail if Indian painting is to advance, just as this has been necessary to the preservation and continuance of other Indian arts. Modern-day pressures have a way of stifling the creative spirit in favor of mass production.

This is not to advocate a benevolent censorship over the work of Indian painters; rather it is to suggest the necessity for more freedom. As Frederic Douglas wrote while curator for the Denver Art Museum, "If this Indian art is to reach its height.... we must forget that it is Indian and think only of it as art. If it tends to develop three dimensions, let it."*

Sixty years of Indian painting have produced several hundred painters sufficiently capable and talented to attract the attention of private collectors and museums both here and abroad. The ability of these artists to depict action; their unerring sense of rhythm and color; their intuitive use of space; their delicate brush work-these are the basic elements. Underlying them is a rich cultural heritage which gives inspiration and direction to their art.

The future, then, of American Indian painting can be as significant as Indian artists and a sympathetic public wish to make it.

Palo Alto, California

Doris Ostrander Dawdy

February Io, I967

* F.H. Douglas, "The Spring Exhibit of Indian Art," El Palacio, XXXVIII (June I2-19-26, I935), I3I. 


\title{
ANNOTATED BIBLIOGRAPHY
}

\author{
of
}

\section{AMERICAN INDIAN PAINTING}

Agogino, George, and Heidi Howe. "Oscar Howe, Sioux Artist," Institute of Indian Studies, State University of South Dakota, November I, I959.

A detailed account of Oscar Howe's life, together with a list of awards, mural paintings, books illustrated for publication, art work published in books and magazines, and art exhibitions.

Alexander, Dr. Hartley Burr. Pueblo Indian Painting. Nice, France: C. Szwedzicki, I932.

A discussion of Pueblo Indian painting. Fifty handsome color reproductions of the following artists' work are included: Julián Martínez, Encarnación Peña, Abel Sánchez, Romando Vigil, Louis Gonzáles, Richard Martínez, Alfonso Roybal (Awa Tsireh), Miguel Martínez and Velino Herrera. At the time the book was written, Dr. Alexander was a professor at Scripps College and a lecturer at the School of American Research.

Alexander, Dr. Hartley Burr. Sioux Indian Painting, Nice, France: C. Szwedzicki, I932.

A discussion of Sioux Indian painting. The book contains many reproductions in color, and is quite comprehensive in treatment of early Sioux painting.

Alexander, Hartley. "The Art of the American Indian," The Nation, I32 (May 6, I93I), 50I-03.

Though this article deals with all media of Indian art on exhibition at the Grand Central Art Galleries in New York, there are several statements relating to Indian painting which are of particular interest.

Alford, Trudy. "Colors of the Earth," Américas, XII (May I960), I7-20. A detailed account of Pablita Velarde's life, together with reproductions of her paintings.

Anonymous. "A Development of the Representation of the Sciences in Abstract Indian Design," Indians at Work, I (June I5, I934), 24-28.

A description of the volunteer mural project of Santa Fe Indian School art students for their social studies class. Included are plates of two of the murals.

Anonymous. "Acee Blue Eagle, Indian Artist," Smoke Signals, (November I952), 7-8.

A brief statement about the work of the versatile Acee Blue Eagle, Creek-Pawnee artist.

Anonymous. "After Losing Right Arm, This Young Indian Becomes Gifted Artist," Indians at Work, VII (July I940), 6-7.

Sam H. Ray, Navajo painter, is the subject of this biographical sketch which includes illustrations of his work at the Consolidated Ute School where he painted murals.

Anonymous. "American Artist," Time, XXXVI (July I5, I940), 50.

Ben Quintana's painting, which won the $\$ \mathrm{I}, 000$ first award in a contest sponsored by American Magazine, is explained in detail. A brief statement about the artist's career follows.

Anonymous. "American Indian Artists Association," Smoke Signals, 47-48 (Winter-Spring, Ig66), 28.

An announcement of recently completed panels by Indian artists George Smith Watchetaker, Stephen Mopope, Herman Toppah, Charles Rowell, and Lee Tsatoke. The artists are members of the American Indian Artists Association of Lawton, Oklahoma. 
Anonymous. "American Indian Drawings," The Brooklyn Museum Quarterly, XVII (April I930), 55-56.

A review of an exhibition at the Brooklyn Museum of colored drawings by Indian artists of the Southwest, including Awa Tsireh and Otis Polelonema. The exhibition was arranged by Dr. Herbert J. Spinden, curator for the Department of Ethnology at the Museum.

Anonymous. "American Indian Painting Awards Are Announced," Architect and Engineer, I99 (December I954), 7 .

An announcement of the award winners in the Indian painting exhibition at M. H. de Young Memorial Museum in San Francisco. They are Richard David Takilnok, Helen Boswell, Gilbert Atencio, Frank Paul Vigil, Noah Deere, Brummett Echohawk, Otis Polelonema and Pablita Velarde.

Anonymous. "American Indian Watercolors Featured This Month at De Young Museum," Architect and Engineer, I54 (July I943), 5.

A review of Southwest Indian painting on exhibition at the M. H. de Young Memorial Museum in San Francisco.

Anonymous. "American Indians," Art Digest, XXV (May I5, I95I), I4. A review of Philbrook Art Center's sixth annual exhibition of contemporary American Indian painting at Tulsa, Oklahoma. Award winners are Acee Blue Eagle, Charlie Lee, Fred Beaver, Oscar Howe, Bert Preston, William Sampson, Dick West, Fred Kabotie, C. Terry Saul and Albin R. Jake. Otis Polelonema, Red Robin, Solomon McCombs, Dwight Phillips, Charles Pushetonequa, Yeffe Kimball, Ernie Farmer and Ermaleen Dawes received honorable mention.

Anonymous. "Among 36r,472 Competitors Santa Clara Indian Boy Wins an Award for Artistic Effort," Indians at Work, VII (September I939), I8.

Eighteen-year old Joseph Tafoya, Jr., receives a Certificate of Merit and a cash award for his entry in the Art Division of the I938-39 American Youth Forum competition sponsored by the American Magazine. He is the winner of various awards in his home state of New Mexico.

Anonymous. "An Indian Artist," Indians at Work, I (February I, I934), 25. A brief summary of the achievements of John L. Clark, Blackfeet Indian artist and sculptor, including the museums where he has exhibited and the awards he has received.

Anonymous. "An Indian Goya Who Amazes Artists," The Literary Digest, LXXXVII (October I7, I925), 44-46.

An article about the Indian artist, Awa Tsireh, with reproductions of his paintings. Alice Corbin Henderson, who knew the artist personally, is quoted at length.

Anonymous. "Annual Contemporary American Indian Art Show - Denver Art Museum," Smoke Signals, (August I953), I2-I3.

A brief statement about Denver Art Museum's third annual. Harrison Begay and Allan Houser received purchase awards. Fred Beaver, F. Blackbear Bosin, Allan Houser, Solomon McCombs, Al Momaday and C. Terry Saul received honorable mention.

Anonymous. "Annual Exhibition of Indian Paintings," El Palacio, LXVII (August I960), I Io.

A brief review of the Museum of New Mexico's fifth annual Indian art exhibition in which 34 students and 43 professional artists participated. Artists Joan Hill, A. Tsihnahjinnie, Narciso Abeyta and James Lujan received awards.

Anonymous. "Annual Indian Painting Exhibition at Philbrook," Smoke Signals, (August I957), 8-9.

A report on Philbrook Art Center's twelfth annual contemporary American Indian exhibition. Indian artists Albin R. Jake and Fred Beaver served on the jury. The following exhibiting artists received awards: Jesse E. Davis, Dick West, F. Blackbear Bosin, Al Momaday, Carl Woodring, Dennis Belindo, Pablita Velarde, Stanley Battese and Charles Lee. Narciso Abeyta, Ascension Trujillo, Acee Blue Eagle, C. Terry Saul, Solomon McCombs, Jimmy Anderson and Joe Waano-Gano received honorable mention.

Anonymous. "Annual Indian School Exhibit," El Palacio, XLVI (May I939), II2-I5.

Reprint of an article in the Santa Fe New Mexican, reviewing an Indian painting exhibition at the Art Museum. 
Anonymous. "Artist Richard West," Smoke Signals, (February I953), 9. A report of a one-man show in Savannah, Georgia, including background material about the career of artist-teacher Richard West.

Anonymous. "Artists with Never a Thought for Fame," The Literary Digest, II6 (September 9, I933), I5.

An article quoting artist Olive Rush on the nature of Indian artists. Oqwa Pi, Awa Tsireh and Tse-ye-mu are mentioned.

Anonymous. "At the Art Gallery," El Palacio, LVII (March I950), 92-93. One-man shows of Indian artists Calvin Chávez and Otis Polelonema at the Museum of New Mexico Art Gallery in Santa Fe are briefly noted.

Anonymous. "Blue Eagle Mural Restoration," Smoke Signals, 47-48 (WinterSpring, I966), 29.

Details of the restoration of a mural painted in 1942 by Acee Blue Eagle. The late artist's friend, Fred Beaver, did the restoration.

Anonymous. "Carl N. Gorman Heads Navajo Arts and Crafts Guild," Smoke Signals, 42 (I964), 9.

An announcement containing some information on the artist's life.

Anonymous. "Contemporary American Indian Painting," Arts, XXX (November I955), 50.

A review of an American Indian painting exhibition at the Graham Gallery in New York City. Tom Two-Arrows, Pablita Velarde, Acee Blue Eagle and Richard West are mentioned.

Anonymous. "Contemporary American Indian Painting Exhibition," Smoke Signals, (November I953), I2-I4.

This article is taken from a news release issued by David E. Finley, Director of the National Gallery of Art in Washington, D.C. It concerns an exhibition opening there on November 8, and continuing through December 6, I953. A statement by Dorothy Dunn concerning Indian painting is included.

Anonymous. "Current American Indian Painting in Denver Art Museum Exhibit," The American Indian, VI (Spring I952), 22-23.

A report of the Denver Art Museum's first contemporary American Indian exhibition. Fred Beaver, Acee Blue Eagle, F. Blackbear Bosin, Franklin Gritts, Oscar Howe, Solomon McCombs, Dwight E. Phillips, C. Terry Saul, Tom Two-Arrows and Calvin Vigil participated. Willena D. Cartwright, curator of Indian art at the museum, is quoted extensively on the nature of the entries as well as the museum's attitude toward Indian painting.

Anonymous. "Dick West Honored by School Show," Smoke Signals, (February I953), I5-I6.

This article was drawn from a news item appearing in the Muskogee Phoenix-Democrat (Oklahoma) concerning the career of Richard West, including a one-man show at the University of Redlands, California, held during October 1952.

Anonymous. Directions in Indian Art. Tucson, Arizona, I959. 3 I pages.

Report of a conference at Tucson in March 1959. The conference was sponsored by the Rockefeller Foundation to explore the future of American Indian art. Several Indian artists are quoted as well as numerous other authorities in the field.

Anonymous. "Earth Tones in Tempera by Talented Indians," Art News, XXXVIII (November II, I939), II.

A review of an exhibition at F.A.R. Galleries in New York. Artists Gerald Nailor, Ku-pe-ru and Alan Houser are mentioned.

Anonymous. "Eighth National American Indian Painting Exhibition - Philbrook Art Center, Tulsa, Oklahoma," Smoke Signals, (May I953), I5-I6. A review of the eighth annual at Philbrook. Andrew Tsihnahjinnie served on the jury. Pablita Velarde, F. Blackbear Bosin, C. Terry Saul, José Rey Toledo, Oscar Howe, Fred Beaver, Joe H. Herrera, Al Momaday and Acee Blue Eagle received cash awards. Bert Preston, Walter Shurley, José Rey Toledo, Frank Brave, Oscar Howe, and Wilbur Walluk received honorable mention. 
Anonymous. "Emmons Announces New Arts and Crafts Course at Santa Fe Indian School," Smoke Signals, (August I960), 9-IO.

An announcement of the opening of a two-year course in arts and crafts at the Santa $\mathrm{Fe}$ Indian School.

Anonymous. "Exhibition of Indian Painting at De Young Museum," Smoke Signals, (February I955), 8-9.

A report of the contemporary American Indian painting exhibition at the M. H. de Young Memorial Museum in San Francisco from November 25, 1954 to January 2, I955. Richard Davis Takilnok, Helen Boswell, Gilbert Atencio, Frank Paul Vigil, Noah Deere, Brummett Echohawk, Otis Polelonema and Pablita Velarde received specific recognition.

Anonymous. "Exhibitions," Smoke Signals, 46 (Autumn, I965), 25. Reproductions of two paintings by Sioux artists Austin Rave and Oscar Howe.

Anonymous. "Exposition of Indian Tribal Arts," Bulletin of the Milwaukee Art Institute, VI (September I932), I-5.

A review by Margaret Breuning of the New York Evening Post. Fred Kabotie, Ma-Pe-Wi, Awa Tsireh, and Oqwa $\mathrm{Pi}$ are mentioned.

Anonymous. "Exposition of Indian Tribal Arts," American Magazine of Art, XXIII (December I93I), 5I6.

A review of the Exposition of Indian Tribal Arts at the Grand Central Art Galleries in New York. Awa Tsireh received first prize. Many of the paintings for this exhibition were donated; the donors are listed.

Anonymous. "Exposition of Indian Tribal Arts," Connoisseur, LXXXVIII (September I93I), 209-IO.

A review of an exhibition of Indian painting at the Grand Central Galleries in New York. Artists Tsa-to-ke, Mopope, Asah and Hokeah are mentioned.

Anonymous. "Exposition of Indian Tribal Arts, Inc.," Indians at Work, III (February I5, I936), 37.

A brief summary of the achievements of the organization in introducing American Indian painting throughout the United States and also in Europe.

Anonymous. "Fifth American Indian Art Workshop," Smoke Signals, 42 (I964), I5.

An announcement of an artists' workshop, conducted by Sioux artist Oscar Howe at the University of South Dakota, Vermillion.

Anonymous. "First Indian Annual," Art Digest, XXVI (October I5, I95I), ro.

A review of the first annual contemporary Indian painting exhibition at the Denver Art Museum. Artists Tom Two-Arrows, Acee Blue Eagle, Solomon McCombs, Fred Beaver, Calvin Vigil, C. Terry Saul and F. Blackbear Bosin are mentioned.

Anonymous. "Folklore," Smoke Signals, 46 (I965), I3-I7.

A portfolio of eight wash drawings by George Burdeau, Blackfeet, with a brief statement about the artist.

Anonymous. "Fourth Annual Exhibition of Contemporary American Indian Painting at the Denver Art Museum," Smoke Signals, (November 1954), 3-4. A review of the subject exhibition. Jose V. Aguilar, Oscar Howe, Otis Polelonema, Theodore Suina and Pablita Velarde received awards.

Anonymous. "Fred Beaver Wins Award," Smoke Signals, (August r954), ro. Note is taken of Fred Beaver's fifth consecutive winning of the first purchase avard at Philbrook's contemporary American Indian painting exhibition in Tulsa, Oklahoma.

Anonymous. "Fred Kabotie Joins Staff of Indian Arts and Crafts Board," Smoke Signals, (November I960-February I96r), Io.

A brief news item listing Fred Kabotie's achievements in art. 
Anonymous. "French Government Gives Art Awards," Smoke Signals, (February I955), 7.

Twelve outstanding Indian artists and craftsmen received Palmes Académique of the French Republic. The artists so honored were Harrison Begay, Fred Kabotie, Joe Herrera, Pablita Velarde, Allan Houser, Awa Tsireh, Andrew Tsihnahjinnie and Ma-Pe-Wi.

Anonymous. "Gerald Nailor," The Masterkey, XXVI (September-October, I952), I68.

A most impressive tribute to the Navajo artist Gerald Nailor following his untimely death.

Anonymous. "Greater Tribal Exhibition Will Reveal Indian's True Place in Art," Art Digest, V (September I, I93I), 5-6.

A review of the Exposition of Indian Tribal Arts at the Grand Central Art Galleries in New York. Artist John Sloan and Jeanne d'Ucel of the University of Oklahoma are quoted. Reproductions of paintings by Auchiah, Wo Peen and Hokeah are included.

Anonymous. "Hopi Native Drawings," The Masterkey, XXVII (JanuaryFebruary I953), 26-7.

An account of Mrs. Laura Adams Armer's experiment in teaching painting to Indian children in 1924 at the Hopi day school in Oraibi, Arizona. Artists R. Poseyesva, Waldo Mootzka and Robert Qotskuyva are mentioned.

Anonymous. "Inaugural Activities," Smoke Signals, 44 (Spring, I965), 34.

Creek artist Solomon McCombs designed floats depicting all segments of Indian life today for the President's Inaugural parade, and also served as a coördinator for the Inaugural activities.

Anonymous. "Indian Art," Art Neres, XXX (June 4, I932), I2.

A report on the reception in Europe of an Indian painting exhibition at the Venice Biennial.

Anonymous. "Indian Art an Asset," El Palacio, XIII (November I5, I922), I24-25.

A reprint of an article in the Shanghai Times, China, relative to Dr. Edgar L. Hewett's talk entitled "The Art of the Earliest Americans," which he delivered at the convention of the American Federation of Art in Washington.

Anonymous. "Indian Art and Artists," El Palacio, VIII (July I920), 2I6-I7. A brief reference to a Pueblo Indian painting exhibition which had received favorable comment. The New York World published a color page supplement, reproducing several paintings and providing text by a New York art critic.

Anonymous. "Indian Art Around the World," Tulsa World Sunday Magazine (Oklahoma), June 30, I957.

A definitive article about the Philbrook Art Center which houses a large collection of Indian paintings. Mention is made of recent purchases of five paintings, bringing the total to 256.86 Indian artists are represented. The works of Robert Chee, Solomon McCombs, Dick West, Fred Beaver, Blackbear Bosin and Acee Blue Eagle are discussed briefly.

Anonymous. "Indian Artists Decorate Interior Murals," Indians at Work, VII (December I939), 4-7.

Discussed briefly are Indian artists Velino Herrera, Gerald Nailor, Allan Houser, Woodrow Crumbo, James Auchiah and Steven Mopope, all of whom were commissioned to do murals in the Department of Interior Building.

Anonymous. "Indian Artist Displays Paintings," Smoke Signals, (February I959), 4-5.

Some highlights in the career of artist Oscar Howe during the year 1958.

Anonymous. "Indian Artists Take Up Mural Painting," Art Digest, VII (January I, I933), 32.

An article about the murals which were added to the 1933 Exposition of Indian Tribal Arts. $\mathrm{Ma}-\mathrm{Pe}-\mathrm{Wi}$, Tse-Ye-Mu, O-Pa-Mu-Nu and Oqwa Pi are mentioned.

Anonymous. "Indian Children Exhibit Paintings and Drawings in Washington," Indians at Work, VI (August I939), 33-34.

An exhibition of Indian art by school children, including Narcisco Abeyta who later gained recognition as an artist. 
Anonymous. "Indian Drawings," The School Arts Magazine, XXX (March I93I), $46 I-63$.

A brief account of the discovery of Indian painting. Artists Velino Shije, Awa Tsireh, Tse$\mathrm{Ye}-\mathrm{Mu}$, Oqwa Pi, Romando Vigil and Tonita Peña are mentioned.

Anonymous. "Indian G.I. Is Internationally Famous Artist," The Christian Science Monitor Magazine, March IO, I945, p. I8.

A biographical sketch of Acee Blue Eagle's career as a muralist and as a lecturer on Indian life. Anonymous. "Indian Paintbrush," Newsweek, XXXVI (September 4, I950), 75 .

A review of an exhibition at the Smithsonian in September 1950. F. Blackbear Bosin, Fred Beaver, Allan Houser and Waldo Mootzka are mentioned.

Anonymous. "Indian Tribal Arts," Art News, XXX (November 7, I93I), I2. Emphasizes the importance of the esthetic side of aboriginal art to artists and connoisseurs.

Anonymous. "Indian Tribal Arts Exhibition Starts on Long Tour of Nation," Art Digest, VI (December I5, I93I), 32.

A review of an exhibition at the Grand Central Art Galleries in New York in which Edward Alden Jewell of the Times, Margaret Breuning of the Post, John Sloan and Oliver La Farge are quoted. A reproduction of a painting by Oqwa $\mathrm{Pi}$ is included.

Anonymous. "Indian Youths Paint Murals for San Francisco Exposition," Indians at Work, VI (April I939), 20.

Joseph Durán, Ignacio Moquino, Charles Loloma and Calvin Larvie are the young artists mentioned in connection with the subject mural project.

Anonymous. "Joe H. Herrera," Smoke Signals, (February I956), 3-4.

Some highlights in the life of Joe Herrera, with particular emphasis on the film "Indian Artist of the Southwest," which was built around his career.

Anonymous. "Kiowa Indian Identifies Inscription," Indians at Work, (January-Febrary I944), 3I.

This article, reprinted from the September 5, 1943, New York Times, gives a detailed account of James Auchiah's discovery of his grandfather's inscriptions made while he was a prisoner at Castillo de San Marcos, an old fort in Florida.

Anonymous. "Little Magic," Time, L (July 7, I947), 69.

An unfavorable review of Philbrook Art Center's second annual Indian art exhibition. Oscar Howe, José Rey Toledo and Ma-Pe-Wi are mentioned. No specific criticism of their work is made, the comment referring to the exhibition as a whole.

Anonymous. "Little No Shirt - Famous Artist," The Amerindian, IX (May-June I96I), 3-4.

A brief account of Beatien Yazz's life as a hero of Alberta Hannum's Spin a Silver Dollar and Paint the Wind, and most recently his illustrations for The Last Horse by Stan Steiner.

Anonymous. "Most Native Art of the U.S.A.-American Painting Today," The Studio, I52 (July I956), I4-I7.

A review of an exhibition of Indian paintings from the College of Fine Arts collection at the University of Oklahoma. Crescencio Martínez is mentioned, and reproductions of paintings by Emiliano Abeyta, Lorenzo Beard, Harrison Begay, Mary Ellen, Pablita Velarde, Andrew Tsihnahjinnie and José Rey Toledo are included.

Anonymous. "Mrs. Roosevelt and Fred Kabotie at Museum of Modern Art Exhibit," Indians at Work, VIII (March I94I), 6.

A brief reference to the Museum of Modern Art's exhibition of Indian creative arts.

Anonymous. "Museum of New Mexico's First Indian Artists Annual," Smoke Signals, (August I956), 9-II.

A report of the Museum of New Mexico's plans for annual juried exhibits of contemporary Indian painting, with a background of Indian painting covering the past thirty-five years.

Anonymous. "Native Indian Artists," Survey Graphic, XXIX (March I940), I75-77.

Reproductions of murals for the Department of Interior building by artists Velino Herrera, Woodrow Crumbo, Gerald Nailor, Allen Houser and James Auchiah. 
Anonymous. "Natural Artists Among Indians," The Literary' Digest, II5 (April S, I933), II-I2.

The story of the mural project at the Santa Fe Indian School under the guidance of artist Olive Rush. A reproduction of a painting by Hokeah appears on page I 2.

Anonymous. "Newark: Paintings by Indians," Art News, XXXVI (January 22, I938), 20.

Some comments on paintings by Pueblo, Hopi, Navajo and Apache artists which were presented to the Newark Museum by Amelia Elizabeth White, a collector of Indian paintings for many years.

Anonymous. "Ig6I American Indian Artists Exhibition at Philbrook," Smoke Signals, (November Ig60-February I96I), 8-9.

An announcement of Philbrook Art Center's annual Indian art exhibition, with background material on Fred Kabotie.

Anonymous. "Notes from Laurance D. Cone, Anadarko, Oklahoma," Sinoke Signals, (August I960), 2-3.

An announcement of a one-man art exhibition of portraits by the Kiowa-Oto artist, Ray Arkeketa.

Anonymous. "Ogden (Utah) Features Art Show by Allan Houser," Smoke Signals, (February I953), I3-I4.

This article was drawn from a news item in the Salt Lake Tribune regarding the career of Apache artist Allan Houser and his one-man show in Ogden.

Anonymous. "Oklahoma Indian Artists Under the Public Works of Art Projects," Indians at Work, I (February I5, I934), 38-39.

Blue Eagle, Mopope, Auchiah, Tsa-to-ke, Jack Hokeah and Spencer Asah are mentioned in connection with art projects in schools and other public buildings in Oklahoma.

Anonymous. "One-Man Show by Albin Jake," Smoke Signals, (August I957), 9-IO.

A report of Albin Jake's one-man show at Philbrook Art Center during May 1957.

Anonymous. "Only Indian Painter in America," Current Opinion, LXXII (January I922), IO4-5.

The story of Hart Merriam Schultz, more popularly known as "Lone Wolf." This self-taught artist, half Blackfeet and half Dutch, was the son of James Willard Schultz, the writer. His painting technique is not traditionally Indian.

Anonymous. "Oscar Howe Honored on Television Show," Smoke Signals, (May I960), I8-I9.

This news item covering Oscar Howe's appearance on "This Is Your Life," includes a statement by Vincent Price on the artist's accomplishments.

Anonymous. "Oscar Howe, Sioux Artist," Smoke Signals, (November I957), 5-6.

An announcement of Oscar Howe's appointment as Assistant Director of the University of South Dakota Museum at Vermillion, and as Assistant Director of the Institute of Indian Studies and Assistant Professor of Fine Arts.

Anonymous. "Pablita Velarde, Indian Artist of the Red Earth Country," New Mexico, XXXVIII (December I960), 5-I3.

Pablita Velarde's life, her philosophy for living, and her interpretation of the Christmas story through her painting are the subjects of this definitive article. Three color reproductions of her paintings, accompanied by Biblical text, are included.

Anonymous. "Philbrook's Annual Indian Painting and Sculpture Show," Smoke Signals, (February I960), I2-I3.

An announcement of Philbrook Art Center's fifteenth annual exhibition, together with a statement of its aims. Oscar Howe, Bruce Timeche, Kivetoruk Moses and Willard Stone are mentioned.

Anonymous. "Press Release," Smoke Signals, (February I959), 8-Io.

Reprint of a press release from Philbrook Art Center, Tulsa, Oklahoma, regarding its annual Indian painting exhibition. Artist F. Blackbear Bosin is mentioned. 
Anonymous. "Prize-Winning Poster for Coronado Cuarto Centennial," Indians at Work, VII (January I940), 9.

Ben Quintana, age I 5 , wins first prize over 80 contestants in poster competition sponsored by the Coronado Cuarto Centennial.

Anonymous. "Pueblo Children Represent the United States in an International Art Exhibit," Indians at Work, II (February I5, I935), 27-28.

Many of the paintings in this exhibition were produced with earth colors. Adetailed account is given on the collecting of suitable clay and sandstone; the repeated pounding, grinding and sifting followed by soaking in water over stated periods of time; the ultimate mixing with glue to give the necessary adhesive quality to the pigments. Under the auspices of the College Art Association, the exhibition toured leading art centers throughout the United States.

Anonymous. "Pueblo Indian Painting," New Mexico Association on Indian Affairs, Indian Art Series, No. I, 4 pages.

The story of Api-Begay and other early Indian painters: Crescencio Martínez, Alfredo Montoya, Awa Tsireh, Tonita Peña, Fred Kabotie, Velino Shije, Oqwa Pi, and Sybil Yazzi. Dr. Edgar L. Hewett is quoted extensively on the subject of Indian painting. Several reproductions of paintings are included.

Anonymous. "Scalped," Art Digest, XV (October I, I940), I5.

An answer to an article entitled "The Vanishing Idiom" which appeared in the August 1940 Art Digest. Odd S. Halseth, archeologist for the City of Phoenix and a former curator for the San Diego Fine Arts Gallery, is quoted extensively. His strong denial of the charges by the New Mexico Association on Indian Affairs and John Sloan's pamphlet "Before and After," that Indians were being taught art in the European tradition rather than their native idiom, is germane to any study of Indian painting.

Anonymous. "Silver Star to a Young Artist," Indians at Work, (I945 Special Issue), 3 .

The circumstances under which Ben Quintana lost his life during World War II, and the posthumous award which followed. Also noted are the art awards received from his entries in the Coronado Quarto Centennial and the American Magazine's Youth Forum contest.

Anonymous. "653 American Youth Forum Art Awards," The American Magazine, I30 (August I940), 24-26.

From 52,587 paintings and drawings, Ben Quintana (age 17 ) received the first award of $\$ \mathrm{I}, 000$. Other Indian artists receiving cash awards in this contest are Quincy Tahoma, Joe H. Herrera, Ignatius Palmer, Ramos Sánchez, Justin Herrera, Balardo Neito and Joe A. Quintana.

Anonymous. "Solomon McCombs, Creek Indian Artist," Smoke Signals, (February I954), 5-6.

Reference is made in this article to a one-man show for Solomon McCombs at Collectors' Corner in Washington, D.C. Considerable background material is included.

Anonymous. "Taos Artist Paints Mural," Smoke Signals, 43 (I965), 38.

An announcement of a large mural by Eva Mirabel for the Veteran's Hospital in Albuquerque, and a completed work for the Planetarium in Pittsburgh, Pennsylvania.

Anonymous. "The Flight of the Thunderbird," Indians at Work, VI (May I939), 40-4I.

An article about the Ute artist Julius Twohy, illustrated with a photograph of him painting a mural at the Children's Refectory at Tacoma, Washington.

Anonymous. "The Indian Art Exhibit under the Public Works of Art Project," Indians at Work, I (May I, I934), 28-29.

Artists Jack Hokeah, Pablita Velarde and Andrew Tsihnahjinnie were represented in this exhibition of paintings for Indian buildings under the Public Works of Art Project. The exhibition was held in Washington, D.C.

Anonymous. "The I960 Philbrook Art Center Awards," Smoke Signals, (May I960), I3.

Awards were made to the following artists: Blackbear Bosin, Carl Woodring, Oscar Howe, Dave Williams, Bronson Edwards, Joan Hill, Woody Crumbo, Solomon McCombs, Fred Beaver, Andy Tsihnahjinnie, Pablita Velarde, Robert Chee, Rafael Medina, Otis Polelonema, Woody Cochran, Dick West, and Willard Stone. 
Anonymous. "The Mural at Mexican Springs," Indians at Work, II (September I5, I934), 32-34.

Charles Keetsie Shirley, Navajo artist, states his objective in the painting of a mural which deals with the problem of erosion in the Southwest.

Anonymous. "The Tribal Arts Show," Art Digest, VI (December I, I93I), II. A review of the Exposition of Indian Tribal Arts at the Grand Central Art Galleries in New York. Awa Tsireh was awarded first prize for a water color.

Anonymous. "The Vanishing Idiom," Art Digest, XIV (August I940), 29. A report of an admonishment from the New Mexico Association on Indian Affairs to those in charge of Indian education to cease teaching art in the European tradition. Mention is also made of John Sloan's pamphlet, "Before and After," which is said to be a convincing document against teaching the European technique to Indians. A reply to this article appeared in the October I, I940 Art Digest under the title, "Scalped."

Anonymous. "To the Aid of Indian Artists," Indians at Work, I (January I, I934), 32-33.

This article deals with the employment of Indian artists for murals and paintings used in Department of Interior buildings which are connected with the administration of Indian affairs, and other governmental buildings located in heavily populated Indian areas.

Anonymous. "Truly Native," Art Digest, X (April I, I936), 26.

A review of an exhibition of Indian paintings at Brooklyn Museum's Gallery for Living Artists.

Anonymous. "Waano Gano, Artist," Indians at Work, VIII (December I940), 22. The achievements of Waano Gano, California artist.

Anonymous. "Woodrow Crumbo," Indians at Work, VII (January I940), 5I. A brief account of this versatile artist's career and his statement regarding the aims of Oklahoma's Bacone College toward developing Indian art. Crumbo was director of Bacone's art department at this time.

Anonymous. "Youthful Descendant of Geronimo Finds Paintings in Stories of His People," Indians at Work, VII (January I940), 27-29.

A biographical sketch of artist Allan Houser drawn from an interview. His statements about subject matter for paintings is particularly interesting.

Ataloa. "The Revival of Indian Art in Oklahoma, "Indians at Work, IV (June I5, I937), 37-43.

A summary of the development of Plains Indian art which takes into account the careers of Spencer Asah, Steve Mopope, Jack Auchiah, Jack Hokeah, Acee Blue Eagle, Woodrow Crumbo, Franklin Gritts, Cecil Dick, Wilson Lewis, Solomon McCombs, Ernest Spybuck, Silver Horn and Naiche. Ataloa was formerly on the staff of Bacone College at Muskogee, Oklahoma.

Austin, Mary. "American Indian Murals," The American Magazine of Art, XXVI (August I933), 380-84.

A discussion of Indian painting technique giving reasons why the Indian artist is so adept at mural painting. Reproductions of work by Tse-Ye-Mu, Julián Martínez, Weakee, Oqwa Pi and Miguel Martínez are included. Velino Shije is mentioned as a participant in Indian art exhibitions at Corcoran Gallery of Art in Washington, D.C., and Rockefeller Center in New York.

Austin, Mary. "Indian Arts for Indians," The Survey, LX (July I, I928), 38I-85. Though the article deals primarily with Indian crafts and Indian design, the author includes an important statement on Indian painting. Fred Kabotie and Awa Tsireh are mentioned.

Bach, Otto Karl. "Indian Painting Techniques," Design, LII (November I950), 7, I8, 20, 24 .

The director of the Denver Art Museum analyzes the differences in materials, techniques and functions of painting among the various tribal groups. A reproduction of a painting by Awa Tsireh is included.

Bahti, Tom. Southwestern Indian Arts and Crafts. Flagstaff, Arizona: KC Publications, I964.

A brief statement (pages ro-rI) about Indian painting from prehistoric to present time with reproductions of paintings by Pablita Velarde, Andy Tsihnahjinnie, Harrison Begay, R. C. Gorman, Charlie Lee, Beatien Yazz, and Ray Naha. 
Barker, Ruth Laughlin. "John Sloan Reviews the Indian Tribal Arts," Creative Arts, IX (December I93I), 444-49.

An interview with artist John Sloan during which he gives his views on the merits of Indian painting. Crescencio Martínez, Awa Tsireh, Fred Kabotie and Velino Shije are mentioned.

Barrie, Steve. "Oklahoma's Outstanding Painter Purchases Home Here," Advocate (Provincetown, Mass.), August I4, I958, p. 6.

A biographical sketch of Yeffe Kimball's career as an artist and art consultant.

Berry, Rose V. S. "American Inter-Tribal Indian Art," Art and Archeology, XXXII (November-December I93I), I46-59, I88.

Though the article deals with various media of art expression, a substantial portion is devoted to painting. Crescencio Martínez, Awa Tsireh, Polelonema, Pina-Yo-Pan, Tsa-To-Ke, Hokeah, Mopope, Asah, Auchiah, Oqwa Pi, Fred Kabotie, Tonita Peña, Ma-Pe-Wi and Bou-ge-tah Smoky are mentioned. Reproductions of their work accompany the article.

Black, Irma Simonton. "American Indian," Art in America, XLVIII (Winter I960), 92-93.

Examples of paintings by II-and I2-year old Indian children from Tesuque Day School, with a few comments on the characteristics of Indian art.

Blumenschein, Ernest L. and Bert G. Phillips, "Appreciation of Indian Art," El Palacio, VI (May 24, I9I9). I78-79.

A discussion of Indian painting: composition, color, feeling. Both authors were members of the Taos Society of Artists at the time this article was written for the Albuquerque Evening Herald and subsequently published in El Palacio.

Boswell, Jr., Peyton. "Yeffe Kimball, in Debut Show, Combines the Old With the New," Art Digest, XX (March I, I946), Io.

A review of a one-man show at the Rehn Galleries in New York during March 1946. Numerous paintings are discussed in detail.

Bramlett, William. "Following an Ancient Indian Trail," Indians at Work, III (March I5, I936), 38-44.

A member of the teaching staff at the Santa Fe Indian School discusses murals painted by art students on the walls of the school in which the development of mankind was portrayed. The following students participated: Woodrow Ball, Felice Cheromiah, Andy Tsihnahjinnie, Narcisco Abeyta, Teofilo Tafoya, Dan Ouiver, Emiliano Yepa, Allan Houser, Cecil Dick, William Sarracino, Bennie Manzanares and Tonita Luján.

Breuning, Margaret. "Yeffe Kimball Interprets Indian Heritage," Art Digest, XXIII (February I5, I949), I5, 33.

A review of Yeffe Kimball's exhibition at the Rehn Gallery in New York with a detailed discussion of various paintings.

Bryan, Nonabah G. Navajo Native Dyes, Their Preparation and Use. Lawrence, Kansas: Haskell Institute. I940; I963. 75 pp.

Thirty-six delightful drawings of plants by the Navajo artist, Charles Keetsie Shirley.

Bulliet, C. J. "Art in Chicago," Art Digest, XXIV (January I, I950), II. A review of an exhibition of Beatien Yazz's paintings at the Mandel Department Store Galleries in Chicago. Joe Aguilar and Gilbert Atencio are mentioned in connection with previous exhibitions at this gallery.

Burchardt, Bill. "Plains Indian Painting," Oklahoma Today, VIII (Summer I958), II-26.

A historical treatment of plains Indian painting in which due credit is given Susan Peters for her discovery of and assistance to Tsa-to-ke, Hokeah, Auchiah, Asah and Mopope. Excellent color reproductions of paintings by Woodrow Crumbo, Allan Houser, Dick West, Oscar Howe, Cecil Dick and Blackbear Bosin, accompany the article; numerous other Indian artists are mentioned.

Cahill, E. H. “America Has Its 'Primitives,"' El Palacio, XII (May I5, I922), I27-30; International Studio, LXXIV (March I922), 80-83.

A definitive article about the early Indian painters: Ta-e, Awa Tsireh, Fred Kiabotie, Velino Shije and Tonita Peña. Two reproductions of paintings are included. 
Caldwell, Richard M. "Ace Among Indian Painters," The Christian Science Monitor Magazine, February 8, I94I, p. I2.

A biographical sketch of Acee Blue Eagle with five reproductions of his work.

Carl, Edward. "Profile of My People," Arizona Highways, December I948, 2 pages.

Edward Carl, who died in his nineteenth year, won the Martin Leisser Memorial Award in I 944 for his painting "Shiprock." A reproduction of this painting accompanies his article.

Cartwright, Willena. "Second Annual Exhibition of Contemporary American Indian Painting," Smoke Signals, (November I952), 6-7.

Brief comments on the Denver Art Museum's "Second Annual" with a list of the exhibiting artists. They are F. Blackbear Bosin, Joe H. Herrera, Theodore Suina, Oscar Howe, Harrison Begay, Bronson Edwards, Allan Houser, C. Terry Saul, W. Richard West, Fred Beaver, Mike Harvier, Donald Hollowbrest, Solomon McCombs, Harrell Northcutt, Geri Spencer and Encarnación Peña.

Cartwright, Willena D. "I95 I Exhibits at the Denver Art Museum," Smoke Signals, (November I95I), 5-6.

The curator of art at the Denver Art Museum writes about its first annual contemporary American Indian painting exhibition. Fred Beaver, Acee Blue Eagle, F. Blackbear Bosin, Dwight E. Phillips, Bronson Edwards, Franklin Gritts, Oscar Howe, Solomon McCombs, C. Terry Saul, Tom Two-Arrows and Calvin Vigil were represented.

Cassidy, Ina Sizer. "A New Trend in Indian Art," New Mexico, XXVIII (April I950), 24, 44-45.

In her "Art and Artists of New Mexico" column, the author discusses the merits of Calvin Fenley Chávez' work and contrasts it with that of other Indian artists. A detailed account of Chávez' early background, art training and exhibitions of his paintings is given.

Cassidy, Ina Sizer. "Fred Kabotie-Hopi Painter," New Mexico, XII (January 1934$), 27,35-36$.

A biographical treatment of the life of this prominent artist including the circumstances under which he lost his real name, "Nah' ka-Movi," during his first day at school.

Cassidy, Ina Sizer. "Indian Art Comes of Age," New Mexico XXXV (February I957), 37, 54-55.

A review of the Museum of New Mexico's 1956 Indian artists exhibition with reproductions of two paintings. Suwa, Ma-pe-wi, José Rey Toledo, Joe Herrera, Oscar Howe, Calvin Vigil, Beatien Yazz and Wo-peen are mentioned.

Cassidy, Ina Sizer. "Indian Artists, Allan Houser, Popchalee, Gerald Naylor," New Mexico, XVI (November I938), 22, 32-33.

A discussion of the work of these three artists and their particular interests as depicted in their paintings.

Cassidy, Ina Sizer. "Indian Murals," New Mexico, XII (February I934), 2324,39 .

The story of the murals in the dining room of the Santa Fe Indian School. The following student artists participated: Romando Vigil, Ricardo Martínez, Miguel Martínez, Weakee, Quoyavema, Paul Tsosie, Edward Lee and his brother Alexander, Albert Hardy, Jack Hokeah and Oqwa Pi. The account of the enthusiasm for mural painting which folowed is most interesting. For the older painters Awa Tsireh, Velino Shije, Julián Martínez and Tonita Peña volunteered their services and were soon painting murals for the school and also for exhibitions in eastern cities.

Cassidy, Ina Sizer. "Indian Painters," New Mexico, XI (October I933), 28, 48-49. The work of Awa Tsireh and Panyo Pin is discussed in some detail and reproductions of their paintings are featured. Fred Kabotie's early influence on Awa Tsireh is mentioned.

Cassidy, Ina Sizer. "Indians and Abstract Art," New Mexico XXVIII (August I950), 28, 64 .

A discussion of the extent to which Indian art falls under the classification of "abstract art." As to the future of Indian painting, the author states the views of Lloyd H. New, Education Specialist in charge of teaching art in Indian schools. Mr. New is a Cherokee Indian from Oklahoma who has worked for the advancement of Indian arts and crafts. 
Cassidy, Ina Sizer. "José Rey Toledo," New Mexico, XIV (December I936), 23,38 .

Highlights in the career of José Rey Toledo and a reproduction of one of his paintings. The significance of the Indian artist's approach to painting is strongly emphasized.

Cassidy, Ina Sizer. "Mootzka, The Painter from Oraibi," New Mexico, XII (July I934), I7, 44.

The story of a Hopi artist without formal art training who enjoyed immediate success upon his move from Oraibi to Santa Fe. A reproduction of one of his paintings is included.

Cassidy, Ina Sizer. "Quoyavema from Hopi," New Mexico, XII (November I934), 2I, 44.

The story of a young Hopi who was taken from his native environment at an early age. Upon his return in later years he became an avid student and painter of Hopi ceremonials. Of particular importance is the part of this article which deals with the Hopi technique of painting figures in the round. Convincing reasons are given to offset the popular supposition that the Hopi learned this techniques from the white man.

Cassidy, Ina Sizer. "Tonita Peña (Quah Ah) - Julian Martinez," New Mexico, XI (November I933), 28, 45-46.

A discussion of the Indian artist's approach to painting followed by an analysis of the work of Tonita Peña and Julián Martínez. Examples of their painting are shown.

Charlot, Jean. "All-American," The Nation, I52 (February 8, I94I), I65-66. A review of an exhibition of Indian painting at the Museum of Modern Art in New York. The author discusses the realistic aspects of Indian art.

Clark, Ann Nolan. Little Herder in Autumn. Little Herder in Summer. Little Herder in Spring. Little Herder in Winter. U.S. Office of Indian Affairs, I940I942. (A series).

Illustrated by the Navajo artist Hoke Denetsosie. A brief account of his background is included.

Clark, Ann Nolan. Singing Sioux Cowboy. Lawrence, Kansas: Haskell Institute, I947. There Still Are Buffalo. Lawrence, Kansas: Haskell Institute, I942. Illustrated by Andrew Standing Soldier, Sioux artist. A brief account of his background is included.

Coates, Robert M. "The Art Galleries," The New Yorker Magazine, XLI (November 27, I965), 228.

Comments on an exhibition at Riverside Museum in New York, based on the catalog and the author's prior knowledge of Indian painting.

Collier, John. "Does the Government Welcome the Indian Artist?" Indians at Work, I (June I, I934), 4-IO.

An article by the Commissioner on Indian Affairs respecting governmental attitudes and policies toward Indian art and other matters. Particularly noteworthy is Commissioner Collier's personal appreciation and understanding of Indian art.

Collier, John. "Editorial," Indians at Work, VII (August I940), I-4.

Significant comments on two documents: (I) a letter regarding the American Youth Forum competition in which Ben Quintana won the top prize of $\$ \mathrm{I}, 000$; (2) a letter from the New Mexico Association on Indian Affairs criticizing the illustrating of books for commercial output by Indian art students.

Collier, Mrs. Charles. "News From Indian Artists Under the Public Works of Art Projects," Indians at Work, I (April I, I934), 37.

An article about Indian artists working at Santa Fe under the direction of Jesse Nusbaum, Director of the Laboratory of Anthropology and Regional Director of Public Works of Art Project in New Mexico and Arizona. Jack Hokeah is mentioned.

Collier, Mrs. Charles. Survey of Indian Arts and Crafts. Published by the U.S. Bureau of Indian Affairs. Washington D.C., April I934, 70 pp.

A directory of Indian artists and craftsmen listed by tribe and by state. 
Collier, Mrs. Charles, and Caroline Thompson. "The Public Works of Art Project and Indians," Indians at Work, I (January I5, I934), I9-2I.

A report on the number of artists employed at Santa Fe and Albuquerque unter the Public Works of Art Project.

Colton, Amy Richards. "The Red Man's Contribution to Our Household Art," Garden \& Home Builder, XIIV (September I926), 3I-32, 62.

A brief description of Indian painting with suggestions how it might be used in the home.

Curtis, Natalie. "An American Indian Artist," Outlook, I24 (January I4, I920), $64-66$.

The story of Miss Angel de Cora, Winnebago artist and designer who taught art and crafts at the Carlisle Indian School during Theodore Roosevelt's administration.

Davis, Linzee W. King. "Modern Navajo Water Color Painting," Arizona Highways, XXXII (July I956), IO-3I.

A definitive article on contemporary Navajo painters with numerous reproductions of their work, both in color and black and white. The artists discussed in detail are Beatien Yazz, Quincy Tahoma, Gerald Nailor, Allen Houser, Harrison Begay, Andy Tsihnahjinnie, Narcisco Abeyta, Stanley Battesse, Keetsie Shirley, Wade Hadley, Charlie Lee and Ed Lee Natay. Four reproductions of Stanley Bahe's work are included.

Davis, Linzee W. King. "Water-Colours of the Navajo Indians," The Studio, I47 (June I954), I78-8I.

The development of Indian painting among the Navajo artists from I930 to the time of this article. Beatien Yazz, Quincy Tahoma, Harrison Begay and Andy Tsihnahjinnie are discussed, and reproductions of their paintings are included. Narciso Abeyta and Keetsie Shirley are represented by one reproduction each.

Deskins, Earl. "Acee Blue Eagle and His Native Art," Design, XXXXI (April I940), 8-IO, 22.

A biographical treatment of the life of Acee Blue Eagle.

DeVinna, Maurice, "Indian Painting Annual," Tulsa Sunday World (Tulsa, Oklahoma) May 5, I957.

The fine arts editor of the Tulsa Sunday World discusses the twelfth annual American Indian painting exhibition at Philbrook Art Center. Albin R. Jake, Fred Beaver and art historian Martin Wiesendanger served on the jury. Mr. De Vinna also gives a detailed account of a oneman show by Jake, the nature of his paintings, and some background data about the artist.

DeVinna, Maurice. "Of American Indian Art," Smoke Signals, (May I96I), I-3. An article reprinted from the Tulsa World which reviews Philbrook Art Center's sixteenth annual American Indian artists exhibition.

Devree, Howard. "The Art Gallery Trail: American Indians," The New York Times, March 29, I936, sec. 9, p. 9.

Included in Mr. Devree's review of New York exhibitions is one at the Gallery of American Indian Art featuring water colors by Ma-Pe-Wi.

d'Harnoncourt, René. "Indian Art for Modern Living," House \& Garden, LXXXIII (June I943), 40, 80-8I.

An interesting tale of a young Sioux artist who painted a mural in the government building at the Golden Gate Exhibition in 1939.

d'Harnoncourt, René. "Letter to Richard West," Smoke Signals, (May Ig60), II.

Letter from the Chairman of the Indian Arts and Crafts Board presenting Certificate of Appreciation to artist Richard West.

Dietrich, Margretta S. "Their Culture Survives," Indians at Work, III (April I5, I936), I8-23; New Mexico, XIV (February I936), 22-23, 45-46; New Mexico Association on Indian Affairs, No. I, Indian Art Series. Santa Fe: I936, under title "Pueblo Indian Painting."

A brief summary of the careers of Api Begay, Crescencio Martínez, Alfredo Montoya, Alfonso Roybal, Tonita Peña, Oqwa Pi, Fred Kabotie and Velino Shije. Sybil Yazzie, a student, is mentioned. 
Dockstader, Frederick J. "Before and After Columbus," Art in America, XLIX (Spring I96I), 24-27.

An article about Indian arts and crafts. Oscar Howe, Joe Herrera, and Carl Woodring are mentioned. Color reproductions of work by Narciso Abeyta, Hosteen Klah, and Fred Kabotie are included.

Dockstader, Frederick J. Directions in Indian Art. Tucson: University of Arizona Press, I959. 32 pp.

A report of a conference held at the University, illustrated with work by several student artists.

Dockstader, Frederick J. Indian Art in America. Greenwich, Connecticut: New York Graphic Society, Ig6I, I962, I966.

A book dealing with Indian craft art. However, it includes a short statement on painting, and reproductions of work by Velino Herrera, Quincy Tahoma, Harrison Begay, Fred Kabotie, Allan Houser, and Blackbear Bosin.

Dockstader, Frederick J. "Southwest Indian Art Conference, University of Arizona, Tucson, Arizona," Smoke Signals, (May I959), I-7.

A penetrating analysis of the factors influencing Indian art. The author, a Commissioner of the Indian Arts and Crafts Board, Department of the Interior, is Director of the Museum of the American Indian, Heye Foundation, New York.

Dockstader, Frederick J. "Symbolism in Indian Art," Smoke Signals, (May I958), IO-I2.

An article classifying Indian art designs used in craft art. Since some of the material can also be applied to Indian painting, this source of information is included here.

Dorman, Margaret. A Study of the Water-color Paintings of Modern Pueblo Indians. Albuquerque, New Mexico: I932. 33 pp. (M. A. Thesis, University of New Mexico.)

A discussion of technique and perspective, including a comparison of Pueblo Indian painting with Chinese and Mayan painting. Tonita Peña, Crescencio Martínez, Fred Kabotie, Awa Tsireh, Velino Shije, and Otis Polelonema are mentioned in detail.

Douglas, Frederic H. "The Spring Exhibit of Indian Art," El Palacio, XXXVIII (June I2-I9-26, I935), I29-32.

The curator of Indian art at the Denver Art Museum reviews an exhibition at that museum. The works of Sybil Yazzi, Po-Qui, Tsihnahjinnie, Agnes Bird, Allan Houser, Um-pah and E. Yepa are mentioned.

Douglas, Frederic Huntington, and René d'Harnoncourt. Indian Art in the United States. New York: Museum of Modern Art, I94I, I949.

A book dealing with Indian craft art. However, it names the following painters and includes reproductions of several paintings: Fred Kabotie, Charles Loloma, Herbert Komoyousie, Victor Cootswytewa, Oscar Howe, Munroe Tsa-to-ke and Awa-Tsireh.

Dunn, Dorothy. American Indian Painting of the Southwest and Plains Areas. Albuquerque, University of New Mexico Press, I968. 429 pp., illustrated. A definitive volume on the subject, by one of the outstanding individuals in the field of Indian art education.

Dunn, Dorothy. "America's First Painters," The National Geographic Magazine, CVII (March I955), 349-377.

A definitive article on Indian painting, its history and its future, with good color reproductions. The following artists are discussed: Api Begay, Crescencio Martínez, Fred Kabotie, Awa Tsireh, Ma-Pe-Wi, Polelonema, Julián Martínez, Pablita Velarde, Twoitsie, Joe Herrera, Quah Ah, Lorenzo García, Gerald Nailor, Harrison Begay, Bennie Tilden, Wilson Dewey, Wilmer Dupree, Calvin Larvie, F. Blackbear Bosin, Walter Richard West, Acee Blue Eagle, Noah Deere, Wade Hadley, Eva Mirabal and Allan Houser.

Dunn, Dorothy. "Awa Tsireh: Painter of San Ildefonso," El Palacio, LXIII (April I956), IO8-I5.

A detailed account of the career of Awa Tsireh. 
Dunn, Dorothy. "Indian Children Carry Forward Old Traditions," Indians at Work, II (May I, I935), 25-30.

The head of the Department of Painting and Design at the Santa Fe Indian School writes about the cultural background of the Indian student and his approach to painting.

Dunn, Dorothy. "Indian Painting Can Progress," El Palacio, LVII (April I950), 99-I08.

The future for Indian artists, both in the traditional and academic approach to painting. The question of perspective and shading is discussed; also the necessity for understanding Indian painting and evaluating it objectively. The following artists are commented upon: Gerónima Montoya, Oscar Howe, Eva Mirabel, Fred Kabotie, Allan Houser, Mra-Pe-Wii, Tsihnahjinnie, Harrison Begay, Ben Quintana, Vicenti Mirabal, Steven Vicenti and Wade Hadley:

Dunn, Dorothy. Indian Paintings from the Margretta S. Dietrich Collection. Santa Fe: The Museum of New Mexico, Ig62.

The Dietrich collection consists of 234 works by I04 artists from 25 tribal divisions, mostly from the Southwest; it is being exhibited widely. Dorothy Dunn, the curator, has included a brief explanation of Indian painting in this brochure.

Dunn, Dorothy. "Nehakije: Apache Artist," El Palacio, LIX (March I952), $7 I-76$.

The brief life and remarkable output of one of the first modern painters of the Apache tribe.

Dunn, Dorothy. "Opportunities for the Indian Painter," Smoke Signals, (February I955), I-4.

An article directed to the Indian artist which is also of value to the researcher in this field.

Dunn, Dorothy. "Oscar Howe, Sioux Artist," El Palacio, LXIV (May-June I957), I67-73.

A detailed account of the artist's career and a review of his one-man show at the Art Gallery of the Museum of New Mexico during January and February 1957.

Dunn, Dorothy. "Pablita Velarde: Painter of Pueblo Life," El Palacio, LIX (November I952), 335-4I.

A detailed account of the artist's career from I932 to I952.

Dunn, Dorothy. "Pueblo Indian Painting," Indians at Work, (Contemporary Arts and Crafts issue; n.d., but probably about I936), 30-3I.

A discussion of the ancient background of Pueblo Indian painting, the media the artists prefer, their keen observation and appreciation of nature. Composition, draftsmanship and color sense are covered.

Dunn, Dorothy. "The Art of Joe Herrera," El Palacio, LIX (December I952), $367-73$.

A detailed account of the career of Joe Herrera, an artist who does non-objective and abstract as well as traditional painting.

Dunn, Dorothy. "The Art of Pablita Velarde," El Palacio, LXIV (JulyAugust I957), 23I-32.

A review of the artist's one-man show in the Hall of Ethnology of the Museum of New Mexico where 2 I paintings in casein tempera and handground earth colors were exhibited.

Dunn, Dorothy. "The Development of Modern American Indian Painting in the Southwest and Plains Areas," El Palacio, LVIII (November I95I), $33 I-353$.

A historical treatment of Plains and Southwest Indian painting from the primitive stage to the present. This article, which provides the nucleus of a book now in progress, is one of the most informative in the field of Indian painting.

Dunn, Dorothy. "The Julius Rosenwald Fund Murals," Indians at Work, III (March I, I936), 26-27.

A discussion of the murals painted by-Emiliano Yepa and Po-Qui for the president's conference room at the Julius Rosenwald Fund offices in Chicago. 
Dunn, Dorothy. "The Studio of Painting, Santa Fe Indian School," El Palacio, LXVII (February I960), I6-27. Condensed in Smoke Signals, (May I960), I-8.

A definitive account of how the art department at Santa Fe Indian School came to be, how it functioned, and what it accomplished. The work of Gerald Nailor, Sybil Yazzi, Stanley Mitchell, Quincy Tahoma, and Andrew Tsihnahjinnie-all early students at the school-is discussed. So is the controversial "Persian painting" issue; Awa Tsireh is mentioned in connection with this technique. Oscar Howe is quoted on the actual training given at the school. A bibliography accompanies the article.

Dutton, Bertha P. "Alfredo Montoya-Pioneer Artist," El Palacio, XLIX (July I942), I43-44.

A brief statement on the life of this early artist.

Dutton, Bertha P. "Indian Arts and Crafts Exhibit at Jémez," El Palacio, LVII (January I950), 2 I.

The curator of ethnology at the Museum of New Mexico in Santa Fe, describes art classes taught by Kiowa artist Al Momaday and his wife at Jémez Day School.

Dutton, Bertha P. (editor). Indians of the Southwest. Santa Fe, New Mexico: Southwestern Association on Indian Affairs, I96I: pp. 59-67.

A concise development of Indian art from its earliest forms to the present time. Dr. Dutton includes considerable data about Awa Tsireh, Alfredo Montoya, Crescencio Martínez, Fred Kabotie, Otis Polelonema, Ma-Pe-Wi, Tonita Peña, Gerónima Cruz, José Rey Toledo, Ben Quintana and many others, including recent art students at the Santa Fe Indian School.

Elkus, Ruth C. "Renaissance of American Indian Painting," National League for Woman's Service, (January I955).

A detailed account of an exhibition of contemporary Indian paintings at the M. H. de Young Memorial Museum in San Francisco, during December I954.

Ellinger, Jr., Edgar. "Hoke Denetsosie, Navajo Artist," Desert Magazine, XV (July I952), I2-I5.

An interview in which the artist tells about his interests and aims. Reproductions of two paintings are included.

Ewers, John Canfield. Artists of the Old West. New York (Garden City): Doubleday \& Co., I965.

The earliest Indian artists of record are Four Bears and Yellow Feather, both Mandans. For an interesting account of them, as well as later efforts by other Plains Indians, see pages II 4 , II 6 , and 203-206.

Ewers, John Canfield. Plains Indian Painting. California: Stanford University Press, I939.

A book on aboriginal American art which is valuable for its basic data on color, design, subject matter and early techniques.

Fisher, Reginald. An Art Directory of New Mexico. Museum of New Mexico and School of American Research: I947. 78 pp.

A New Mexico art directory which includes the following Indian artists: Narciso Abeyta, Harrison Begay, Manuel Chávez, Joe H. Herrera, Velino Herrera, James Humetewa, George Keahbone, Al Momaday, Gerald Nailor, Tonita Peña, Pop Chalee, Alfonso Roybal (Awa Tsireh), Harry Sakyesva, Quincy Tahoma, José Rey Toledo, and Steve Vicenti.

Flint, Ralph. "Tribal Arts of the Indian Now on Exhibition," Art News, XXX (December 5, I93I), 5, 8.

A review of the Exposition of Indian Tribal Arts exhibition at Grand Central Galleries in New York.

Forbes, Anne. "A Survey of Current Pueblo Indian Painting," El Palacio, LVII (August I950), 235-5I.

A fairly complete list of Pueblo artists with comments on their careers. 
Forbes, Anne. Report on Survey of American Indian Arts and Crafts: Southwest and Northern Plains. Fall, I958. I3 pp.

Nimeographed report on the present status of Indian arts and crafts, including recommendations for marketing and exhibiting on a larger scale. Problems facing Indian painters are well covered.

Frankenstein, Alfred. "Survey of Indian Art at de Young Museum," The San Francisco Chronicle, December I, I954, p. 23.

A stern criticism of the uniformity in the method and approach of Indian artists to their painting. Only Oscar Howe, Helen Boswell, George Morrison and Yeffe Kimball are credited with being creative and individual in their painting.

Fried, Alexander. "Indian Art at De Young Museum," San Francisco Examiner December 5, I954.

An enthusiastic account of the de Young exhibition in which paintings by the following artists are discussed: Brummett Echohawk, George Morrison, Yeffe Kimball, Richard Takilnok, Carl Gorman, Helen Boswell, Gilbert Atencio and Frank Paul Vigil.

Gebhard, David. "Contemporary Southwestern Indian Painting," Roswell Museum Bulletin, T (Winter I957), 6-8.

An analysis of Indian painting by the director of the Roswell Miseum. The work of Harrison Begay, Gerald Nailor, Stanley Battesse, Apie Begay, Alfredo Montoya, Crescencio Martínez, Fred Kabotie, and Awa Tsireh is discussed in detail.

Hannum, Alberta. "Little No-Shirt," Colliers, II3 (March 4, I944), 56-57. An article about Beatien Yazz, age I3, together with seven reproductions of his work.

Hannum, Alberta. "Navaho Boy Paints Wild Life," The Christian Science Monitor Magazine, December 29, I945, p. 6.

A brief statement about Beatien Yazz with two reproductions of his paintings.

Hannum, Alberta. Paint the Wind. New York: The Viking Press, I958.

The story of the Navaho artist, Beatien Yazz, from the time of his enlistment in the Marines during World War II to I958. Eight pages of color reproductions of his paintings are included.

Hannum, Alberta. Spin a Silver Dollar. New York: The Viking Press, I945. The boyhood years of Beatien Yazz, with color reproductions of his early paintings.

Hansen, L. Taylor. "The Mudhead and Watersnake; Symbol of the Red Land," Search, 65 (September, I965), 9 .

A full-color painting of the Mudhead and Palolokon ritual by the Hopi artist, Kyrat Tuvahoema, appears on the cover.

Hartley, Marsden. "The Scientific Esthetic of the Redman," Art and Archaeo$\log y$, XIII (March I922), II3-I9.

An article dealing with all aboriginal media of artistic expression among Indians which contains some material that is applicable to contemporary Indian painting.

Henderson, Alice Corbin. "A Boy Painter Among the Pueblo Indians and Unspoiled Native Work," The New York Times Magazine, September 6, I925, pp. I8-Ig.

Mrs. Henderson describes her acquaintance with Awa Tsireh. In addition she compares the work of the paleolithic artists and the Indian artists, and states the differences between Pueblo and Plains Indian art. Fred Kabotie, Velino Shije and Crescencio Martínez are mentioned and reproductions of four paintings by Awa Tsireh are included.

Henderson, Alice Corbin. "Indian Artists of the Southwest," The American Indian, II (Spring I945), 2 I-27.

A discussion of the primitive aspects of contemporary Indian painting; also the law of optics and the similarity between Indian and Oriental painting in this respect. An account of the following artists is given: Velino Shije, Otis Polelonema, Awa Tsireh, Alfredo Montoya, Crescencio Martínez, Fred Kabotie and Tonita Peña. 
Henderson, Alice Corbin. "Modern Indian Painting," Introduction to American Indian Art, Part II. New York: The Exposition of Indian Tribal Arts, Inc., I93I. Pp. 3-II.

A discussion of the objective aspects of Indian art, its cultural background, and the attitude of the Indian toward his art. Reproductions of paintings by Quah Ah, Spencer Asah, Fred Kabotie and Awa Tsireh are included.

Hewett, Edgar Lee. "Crescencio Martinez-Artist," El Palacio, V (August 3, I9I8), 67-69.

The director of the School of American Research outlines the significant contribution of one of the first Indian artists.

Hewett, Edgar Lee. "Native American Artists," Art and Archaeology, XIII (March I922), IO3-I2.

The educational background of Awa Tsireh, Fred Kabotie and Velino Shije with reproductions of their Indian ceremonial paintings. Crescencio Martínez is mentioned briefly. The author's statements regarding the significance of religion to Indian painting are of particular interest.

Hewett, Edgar Lee. "The Indian Ceremonies," Art and Archaeology, XVIII (November-December I924), 207-I4.

Reproductions of eight ceremonial dance paintings by Awa Tsireh and Fred Kabotie with a detailed description of each dance.

Hogue, Alexander. "Pueblo Tribe Aesthetic Giants, Indian Art Reveals," El Palacio, XXIV (March 24, I928), 2I4-I8.

An enthusiastic report on Indian art which classifies it as sophisticated and comparable to Chinese and Japanese art. The work of Awa Tsireh, Oqwa Pi, Richard Martínez, Julián Martínez, Tonita Peña, Santiago Cruz, Tse-Ye-Mu, Patricio Toya, Otis Polelonema and MaPe-Wi are mentioned.

Howard, Adrian. "Keetsie-Navajo Artist," Desert Magazine, II (June I939), I9-2I, 3I.

A biographical treatment of the life of Charles Keetsie Shirley. Reproductions of his paintings are included.

Howe, Oscar. "Buffalo Dancer," Institute of Indian Studies, Occasional Papers, State University of South Dakota, November I, I959.

A detailed discussion of the artist's prize-winning painting, "Buffalo Dancer," which received the highest award at the I958 Museum of New Mexico, Indian artists' exhibition.

Hurt, Amy Passmore. "Pop Chalee," New Mexico Sun Trails, V (April I952), IO-II.

A summary of the achievements of the Taos Pueblo artist, Pop Chalee, with two reproductions of her paintings.

Hyatt, Robert M. "He's Giving the Indians a Break!" New Mexico Sun Trails, VI (January I953), 35-37.

An article about Woodrow Crumbo's silk-screen studio in Taos, New Mexico, and his plans for making it a craft center for Indian artists and craftsmen. Four reproductions of his work accompany the article.

Jacobson, O. B. Kiowa Indian Art. Nice, France: C. Szwedzicki, I929.

The director of the art school of the University of Oklahoma discusses the nature of Indian painting. 30 handsome color plates representing the work of Monroe Tsa-to-ke, Steve Mopope, Jack Hokeah, Spencer Asah and Miss Bou-ge-tah Smokey are included.

Jacobson, O. B., and Jeanne D'Ucel. American Indian Paintings, Vol. I. Nice, France: C. Szwedzicki, I950. I9 pages text: 36 color plates.

This handsome volume gives an account of the origins of subject matter used by Indian painters of the Plains and Woodland Tribes with explanations of their interpretations.

Jacobson, O. B., and Jeanne D'Ucel. American Indian Paintings, Vol. II. Nice, France: C. Szwedzicki, I950. I3 pages text: 4I color plates.

This equally handsome volume covers the work of Navajo, Apache, and Pueblo artists, but the tribal characteristics of their painting are analyzed in Volume I. Both volumes contain biographical sketches of the artists. 
Jewell, Edward Alden. "A Tradition Lives On," The New York Times, December 6, I93I, sec. 9, p. I8.

A discussion of Indian abstract painting as an art form, and a review of an Indian painting exhibition at the Grand Central Galleries in New York.

Jones, Hester. "Gerald Nailor, Famous Navajo Artist, I9I7-I9j2," El Palacio, LIX (September I952), 294-95.

The curator of art at the Museum of New Mexico in Santa Fe discusses the art of Gerald Nailor.

Jones, Hester. "Museum of New Mexico's Second National Traveling Exhibition of Contemporary Southwestern Indian Paintings," El Palacio, LXIII (January I956), 3-5.

A report on the reaction of eastern newspapers to the subject exhibition. A list of the partici. pating artists is included.

Jones, Hester. "I956 Indian Artists Exhibition," El Palacio, LXIII (September-October I956), 2\$S-gI.

A review of the subject exhibition which gives considerable information about the nature of Indian painting. The work of the following exhibition artists is commented upon: Suwa, Oscar Howe, Joe Herrera, Ma-Pe-Wi, José Rey Toledo, Ku-pe-ru, Beatien Yazz, Otis Polelonema, Wo-Peen, Harrison Begay, Quincy Tahoma, Gilbert Atencio and Kai-Sa.

Keyes, Helen Johnson. "Indians as Seen in Their Paintings," The Christian Science Monitor Magazine, July 20, I940, pp. S-9.

A review of an exhibition at F.A.R. Galleries in New York. Gerald Nailor, Allan Houser, Acee Blue Eagle, Pop Chalee, Ku-pe-ru, Chiu-tah and Ha-so-de are discussed and illustrated.

Kimball, Yeffe. "Tulsa Accords Recognition to Our Indian Art," Art Digest, XXI (August I, I947), I2, 30.

A review of an exhibition at Philbrook Art Center in which the author shows the similarity of Indian and Brzantire conventions respecting painting, and the consequent break which followed in both instances. Tsa-To-Ke, Ma-Pe-Ti, MIopope, Mootzka and Oqwa Pi are mentioned as pioneers of modern Indian painting, and a list of the prizewinners is given.

Kimball, Yeffe. "Tulsa Surreys U.S. Indian Art," Art Digest, XXII (July I, I94S), II.

A review of the third annual Indian painting exhibition at Philbrook Art Center which contains considerable material on the nature of Indian painting. A list of the prizewinners is included.

Laboratory of Anthropology. Modern Masterpieces of American Art. Santa Fe, New Mexico: Laboratory of Anthropology. n. d.

Serigraphs of work by Allan Houser, Oqwa Pi, Harrison Begay, Gerald Nailor, Ku-pe-ru, and Wade Hadley, with text by Margaret Stewart Dietrich. A very impressive project.

La Farge, Oliver. A Pictorial History of the American Indian. New Iork: Crown Publishers, Inc., I956.

Numerous reproductions of paintings by Indian artists with a brief explanation about each are used to illustrate this pictorial history. A few general statements about Indian painting may be found on pages 254 and 256 .

Lange, Charles H. Cochiti, A New Pueblo, Past and Present. Austin: University of Texas Press, I959. Pp. I79-SI.

This book includes the painting morement at Cochiti, and mentions the following artists: Tonita Peña, Joe Herrera, Theodore Suina, Cipriana Romero, Manuel "Bob" Chavez, Andrew Trujillo, Victor Herrera, and Ben Quintana.

Le Viness, W. Thetford. "Dancing Indians Are His Subjects," Desert Magazine, XII (August I949), I5-I7.

An article about Joe Herrera which gives his ideas about the future of Indian painting.

Le Viness, W. Thetford. "Pablita of Santa Clara Pueblo," Desert Magazine, XIX (September I956), 24-26.

An article about the artist's life, with a description of her earth-painting technique. Three reproductions of her work are included. 
Le Viness, W. Thetford. "Pablita Velarde: Pueblo Painter," American Artist, 29 (April, I965), 40-45, 76-78.

Eleven reproductions of Miss Velarde's paintings illustrate the text of this excellent article which covers the artist's life to the present time.

Lemos, Pedro J. "Have We Any American Art," School Arts Magazine, XXXVI (November I936), I3I.

An editorial pointing up the importance of our American heritage in the art of the Indian.

Lemos, Pedro J. "Mootzka, the Hopi Artist, Painter of Indian Tribal Ceremonies," School Arts Magazine, XXXIV (March I935), 4I7.

A brief summary of Mootzka's background with an evaluation of his work. Included are four reproductions of his paintings.

Lemos, Pedro J. "Our First American Artists," School Arts Magazine, XXXIII (September I933), I0-36.

An article dealing with all the Indian arts which contains a section on Indian painting. Tonita Peña, Fred Kabotie, Oqwa Pi, Ma-Pi-We, Awa Tsireh, Tse-ye-mu and the Vigil brothers are mentioned.

Lemos, Pedro J. "Quincy Tahoma, Navajo Artist," School Arts Magazine, XLII (June I943), 344, 344c.

A brief statement about the artist and his work with two reproductions of his paintings.

Levin, Beatrice. "Vigorous Revival of Indian Art Forms," El Palacio, LX (February I953), 52-56.

Artist Acee Blue Eagle is quoted extensively on the subject of Indian craft arts. He comments only briefly on painting and sculpture.

Liggett, Lila Nol. "Artist on the Warpath," Independent Woman, XXIII (February I944), 46-47, 6I.

An interview with Tonita Peña. Considerable material on her background is included.

Liggett, Lila Nol. "She Proves that Indian Art Is Art," Independent Woman, XXVI (September I947), 256-58.

An interview with Pop Chalee in which she is quoted on the position of Indian art.

Malin, Edward. "Folklore - Art of the American Indian and Eskimo," Smoke Signals, 46 (Autumn, I965), 3-I2.

Though the article does not deal with painting, there are on page II three reproductions: a stone block print by Louis Seeganna, Eskimo; a casein by Solomon McCombs, Creek, and an oil and collage by Earl Eder, Sioux. Explanatory notes are included.

Millington, C. Norris. “American Indian Water Colors," The American Magazine of Art, XXV (August I932), 83-92.

An article about Indian artists who have received international recognition: Jack Hokeah, Steven Mopope, Monroe Tsa Toke, James Auchiah and Spencer Asah. Reproductions of paintings by Otis Polelonema, Fred Kabotie, Oqwa Pi, Awa Tsireh, Tonita Peña, Spencer Asah, Ma-Pe-Wi and James Auchiah are included. The artist Wo-Peen is mentioned.

Mitchell, Mary L. "Indian Paintings, the Ideal, the Different Christmas Gift," New Mexico, XXXVIII (December I960), 38-45.

The origin of art expression among Indians by the arts and crafts department head at Santa Fe Indian School. Reproductions of work by Beatien Yazz, Andy Tsihnahjinnic, Frank Vigil, Robert Chee, and Joe Herrera are included. Anthony Da and Quah Ah are mentioned; Joe Herrera and Harrison Begay are discussed in some detail.

Moore, Irene. "The Ladies Launch a Gallery," American Forests, 7 I (March, I965), 22-25.

A timely article about the Department of the Interior's new gallery which has featured several exhibitions of Indian paintings. The work of Caroline Orr, Fritz Scholder, and Woodworth Henry is sufficiently well reproduced to be of interest. 
Mullan, Read. Gallery of Western Art. Phoenix, Arizona: Universal Litho, Ig64.

Numerous reproductions in black and white of paintings by well-known Indian artists, with a complete list in the catalog at the back which includes title of painting, medium, size, and artist's name.

Myers, J. Preston. The Oraibi Book of Indian Designs For Arts and Crafts or Decorative Work. Copyrighted I930 by J. Preston Myers.

This collection of authentic designs was assembled with the assistance of Waldo Mootzka, Kyrat Tuvahoema, Emerson Quanno, Felix Coin and Clarence Honani, Hopi artists.

New Mexico, a Guide to the Colorful State. Compiled by Workers of the Writers' Program of the Work Projects Administration in the State of New Mexico. New York: Hastings House, I940. pp. I6I-62, I68.

A brief account of the origin and development of Indian painting in New Mexico. Awa Tsireh, Fred Kabotie, Ma-Pe-Wi, Tonita Peña, Crescencio Martínez and Paul Flying Eagle Goodbear are mentioned.

New Mexico Association on Indian Affairs. New Mexico Indians, A Pocket Handbook. Santa Fe, New Mexico: I94I. 26-27.

A section of this handbook is devoted to Indian painting, the medium and technique used, and the establishment of an art department at the Santa Fe Indian School.

Pach, Walter. "Notes on the Indian Water-Colours," The Dial, LXVIII (March I920), 343-45.

A discussion of ceremonial paintings by Kabotie and Shije in which the effect of instinct is noted.

Pach, Walter. "The Art of the American Indian," The Dial, LXVIII (January I920), $57-65$.

An article devoted to the nature of Indian painting, including a comparison with European painting techniques.

Pennington, Robert. Oscar Howe, Artist of the Sioux. Dakota Territory Centennial Commission: I96I. 6I pp.

A detailed account of the life and career of Oscar Howe, with numerous reproductions of his work in black and white, and one in color. Oscar Howe is a professor of fine arts at the State University of South Dakota.

Poage, Evelyn. "War Paint and Water Color," New Mexico Sun Trails, V (July I952), 23-24, 50.

A detailed account of the life and work of José Rey Toledo, with a reproduction in color of his painting. The work of Gerald Nailor, Allan Houser, Don Nash, and Pablita Velarde also is included.

Pop Chalee (Blue Flower). "My People's Art," School Arts Magazine, XXXVI (November I936), I46-47.

An article about Indian painting from an Indian artist's point of view.

Price, F. Newlin. "The Colorful Art of Modern Indians," Arts \& Decoration, XXXVII (August I932), 54.

A description of Indian painting. The following artists are mentioned: Awa Tsireh, Crescencio Martínez, Fred Kabotie, Julián Martínez and Tse-Ye-Mu.

Quintana, Ben. "I Discover America," The American Magazine, I3I (April I94I), 5I-52.

The winner of the $\$ \mathrm{I}, 000$ first award in a project sponsored by The American Magazine tells about his ideas for the painting which won the prize.

Rehnstrand, Jane. "Young Indians Revive Their Native Arts," School Arts Magazine, XXXVI (November I936), I37-44.

A report on the establishment of an Indian art department under Dorothy Dunn at the Santa Fe Indian School. Steven Vicenti is cited as an example of the successful artist whose training at this school enabled him to paint professionally. 
Robinson, Francis W. "A Gift of Water Colors by Pueblo Indians," Bulletin of the Cincinnati Art Museum, IX (January I938), I-I3.

A summary of the development of Indian painting from I9I 8 to 1938. The Kiowa artists Monroe Tsa-toke, Steve Mopope, Spencer Asah, Jack Hokeah and Miss Bou-ge-tah Smokey are mentioned in connection with their European recognition. The names of the artists whose paintings were donated are listed.

Rush, Olive. "Annual Indian Art Show," El Palacio, XLII (May I2-I9-26, I937), I05-08.

A review of the Santa Fe Indian School exhibition. The paintings of the following artists are discussed: Sybil Yazzi, Ned Notah, Pop-Chalee, Juan Medina, Jose García, Tony Martínez, Pablita Velarde, S. C. Mitchell, T'o Pove and Juan Gutiérrez.

Rush, Olive. "The Young Indians Work in Old Forms," Theatre Arts Monthly, XVII (August I933), 635-38.

An article about the native artistic talent of Indian artists, and their approach to painting. Reproductions of work by Julián Martínez, Awa Tsireh, Quah Ah, Fred Kabotie and Raymonde Roybal are included. Oqwa Pi, Waldo Mootzka, Ma-Pe-Wi and Tse-Ye-Mu are mentioned.

Sergeant, Elizabeth Shepley. "An American-Indian Artist," The Freeman, VII (August 8, I923), 5I4-I5.

An article about Awa Tsireh and his work. At this time he was only about 25 years of age, and the foremost Indian artist in New Mexico.

Seton, Marie. "American Indian Painting," The Studio (London), I2I (February I94I), 40-45.

A summary of the development of Indian painting with emphasis on the similarity to Oriental painting. Reproductions by Narciso Alberto, J. B. Medina, Gerald Naylor, Allan Houser, Ku-pe-ru, José Rey Toledo and Tony Martínez, with explanations of their work, are included.

Shaefer, Mathilde. "Winter in Navajoland," Arizona Highways, XVI (December I940), 8-II, 35 .

A biographical treatment of the life of Hoke Denetsosie, Navajo artist and illustrator. Reproductions of his drawings are included.

Sharp, Marynell. "Contemporary American Indian Painting," Art Digest, XXIII (September I5, I949), I9.

A review of an exhibition of Indian paintings at Carlebach Gallery in New York City during September 1949. William Dewey, Ha-a-Tee, Gerald Nailor and Andy Tsihnahjinnie are mentioned.

Shaw, Lloyd. "The Indian as an Artist," Four Lectures in the Fine Arts. Colorado Springs: Colorado College Publication, March I936. 53-73.

A definitive lecture on Indian painting by the superintendent of Cheyenne Mountain High School.

Sheets, Nan. "33 Artists, Prize-Winners All: Indian Works Now on Display," The Daily Oklahoman (Oklahoma City), April I3, I958.

A review of an exhibition at the Oklahoma Art Center in Oklahoma City. A list of the participating artists is included.

Sloan, John, and Oliver LaFarge. Introduction to American Indian Art, Part I. New York: The Exposition of Indian Tribal Arts, Inc., I93I. pp. 5-9; Indians at Work, III (February I5, I936), 38-39.

A discussion of the innate talent of the American Indian in the arts and how his heritage is carried over into his painting. Reproductions of work by Ma-Pe-Wi, Tonita Peña, Awa Tsireh, Oqwa Pi and Fred Kabotie are included.

Sloan, John, and Oliver LaFarge. "Life is Art," Indians at Work, IV (September I5, I936), I4-I5.

A statement regarding the teaching of art to Indian students prior to the reversal in governmental policy. 
Sloan, John. "The Indian as Artist," Survey, LXVII (December I, I93I), 243-46.

An article stating the purposes for which the Exposition of Indian Tribal Arts was organized. Reproductions of paintings by Ma-Pe-Wi, Hokeah, Oqwa Pi and Tsa-to-ke are included.

Snodgrass, Jeanne M. "Philbrook Art Center and the American Indian Annual Painting Exhibition," Smoke Signals, (May I958), 7-9.

The curator of American Indian art at Philbrook Art Center describes the development of Indian art exhibitions at the museum. She lists the winners of its thirteenth annual exhibition.

Speaker, Helen Shield. "She Breathed the Air of the Gods," Desert Magazine, II (October I939), 3-5.

An interview with Pop Chalee. Her ideas about art, and her career as an artist and the mother of two children are interestingly told.

Spinden, Herbert J. "Artists of the Southwest," International Studio, XCV (February I930), 49-5I, 86.

The basis of Indian painting is explored, and a brief summary of the development of Pueblo Indian art is given. A comparison of Pueblo and Kiowa painting is made. The following artists are mentioned: White Bear, Homovi, Crescencio Martínez, Alfredo Montoya, Awa Tsireh, Oqwa Pi, Ricardo and Julián Martínez, Ma-Pe-Wi, Tonita Peña, Fred Kabotie and Otis Polelonema.

Spinden, Herbert J. "Fine Art and the First Americans," Indians at Work, III (January I5, I936), 45-48; Introduction to American Indian Art, Part II. New York: The Exposition of Indian Tribal Arts, Inc., I93I. pp. 3-8.

A discussion of the painting styles of Awa Tsireh, and the restrictions on subject matter which Pueblo painters face. Oqwa Pi, Tonita Peña, Velino Shije, Fred Kabotie and Otis Polelonema are mentioned.

Spinden, Herbert J. "Indian Art on Its Merits," Parnassus, III (November I93I), I2-I3.

An article on understanding Indian painting. A reproduction of a painting by Wo-Peen is included.

Spinden, Herbert J. "Indian Symbolism," Introduction to American Indian Art, Part II. New York: The Exposition of Indian Tribal Arts, Inc., I93I. p. 3-4.

An article about what constitutes symbolism in American Indian art and what does not.

Tanner, Clara Lee. "Contemporary Indian Art," Arizona Highways, XXVI (February I950), I2-29.

A definitive article on Indian painting. Many Southwestern Indian painters are discussed in detail, and reproductions of their work in color and black and white are shown.

Tanner, Clara Lee. "Fred Kabotie, Hopi Indian Artist," Arizona Highways, XXVII (July I95I), I6-29.

A detailed account of the artist's life and work, with color reproductions of his paintings.

Tanner, Clara Lee. "Southwestern Indian Watercolors," The Kiva, XX

(December I954-February I955), II-I4.

The origin of contemporary styles and techniques found in Southwestern Indian painting, together with a resumé of artists contributing to its development.

Tanner, Clara Lee. Southwest Indian Painting. Tucson, Arizona: University of Arizona Press-Arizona Silhouettes, I957. I44 pp.

A history of Southwest Indian art by a member of the University of Arizona faculty, Department of Anthropology. Since 1932, Mrs. Tanner has been actively engaged in the study of Indian cultures and has written many articles, several of which are devoted to Indian painting. This book is a comprehensive account of her findings. Many handsome color reproductions of Indian paintings are included. 
Tanner, Clara Lee and Anne Forbes, "Indian Arts Fund Collection of Paintings," El Palacio, LV (December I948), 363-80.

A discussion of the murals of Awátovi and Kuaua as background for Pueblo painting, with a brief summary of the origin and use of watercolors. Following this introduction the authors discuss the work of the artists comprising the Indian Arts Fund Collection. They are WhiteBear, Homovi, Apie Begay, Julián and Crescencio Martínez, Alfredo Montoya, Awa Tsireh, Fred Kabotie, Otis Polelonema, Velino Herrera, Tonita Peña, Quincy Tahoma, Harrison Begay, Gerald Nailor, Tsihnahjinnie, Oqwa Pi, Tomás Vigil, Roland Durand, Albert Looking Elk, and Kiowa artists Asah, Auchiah, Blue Eagle, Hokeah, Mopope and Tsa Toke.

Teigen, Regina. "Indian Watercolors at Sioux Falls, S.D.," The American Magazine of Art, XXII (April I93I), 304-05.

The supervisor of art for the public schools at Sioux. Falls writes about the reaction to Indian painting of some 7000 school children who attended the exhibition. Artists Asah, Auchiah and Kabotie are mentioned.

Tsa Toke, Monroe. The Peyote Ritual. San Francisco, California: The Grabhorn Press, I957. 66 pp.

A description of the visions and ritual connected with the peyote cult as related to Leslie Van Ness Denman by Monroe Tsa Toke. Fourteen full-page color reproductions of this artist's work, inspired by the ritual, are included. Tsa Toke gives his interpretation of Indian art, and Susan C. Peters contributes information on his life.

Underhill, Ruth M. Pueblo Crafts. Bureau of Indian Affairs, Phoenix, I945.

A brief summary of Indian painting from the early kiva wall murals to the present with reproductions of paintings by Charles Loloma, Alfredo Montoya, Awa Tsireh, Fred Kabotie, MaPe-Wi, Tonita Peña and Wo-Peen. Pop Chalee's work is mentioned with that of the above-named painters.

Vaillant, George C. Indian Arts in North America. New York: Harper \& Bros., I939.

A book dealing primarily with craft art which includes reproductions of paintings by Lorencita Atencio, Fred Kabotie and Awa Tsireh.

Velarde, Pablita. "How and Why Stories," Indian Life, 40 (August, I96I), 23-26.

Stories of Santa Clara Indians, told and illustrated by the author, a Santa Clara artist. The six reproductions are in color, and each illustrates a different story.

Velarde, Pablita. Old Father the Story Teller. Dale Stuart King, Globe, Arizona: Ig60. $66 \mathrm{pp}$.

Six charming Indian stories, written and illustrated by Pablita Velarde, the Santa Clara Pueblo artist. There are seven full-page plates, six of which are in color, and numerous small illustrations. A beautiful book.

Warde, Merry "Artist Oscar Howe Interviewed on Campus by DWU Student Member," Smoke Signals, (November I954), 3.

A reprint of an article from the Middle Border Bulletin, Mitchell, South Dakota.

Weber, Dave. "Arts and Artists," The New Mexican, August I, I954.

A definitive article on contemporary Indian painting in which most of the Southwestern Indian artists are named.

Whigham, H. J. "Editor's Page," International Studio, IC (August I93I), 6. A preview of the Exposition of Indian Tribal Arts prior to its opening in New York. A reproduction of a painting by Hokeah is included.

Wo-Peen. "Indian Art," Southwestern Lore, II (December I936), 48.

A San Ildefonso artist interprets Indian art from the Indian point of view. 




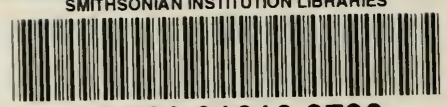

39088016102790 